\title{
Skyd politikerne!
}

Destruktion af RSG-6 og den situationistiske avantgardes politiske former

Mikkel Bolt

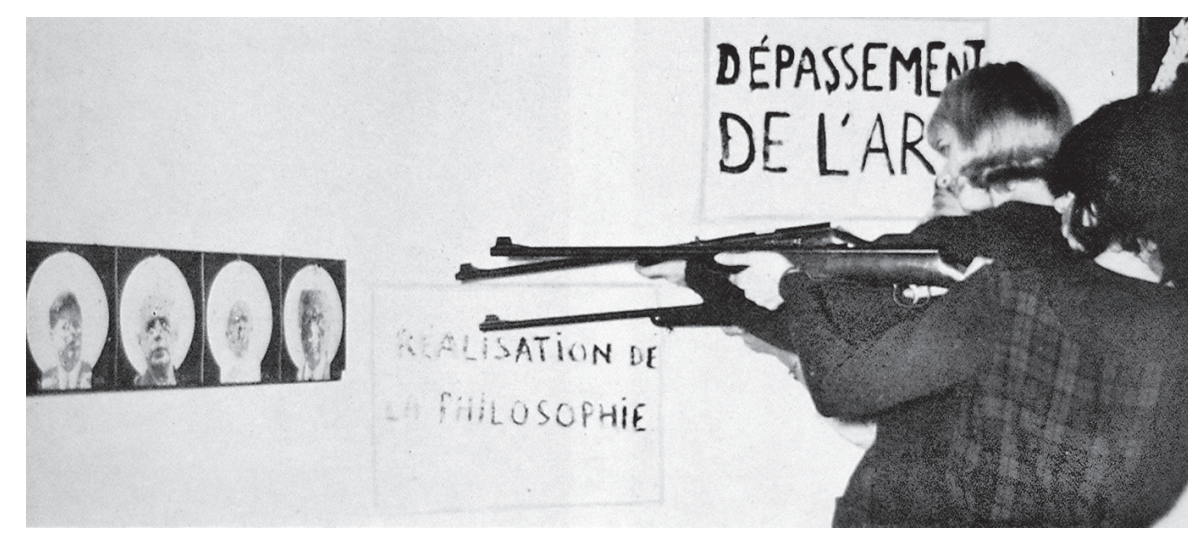


Relationerne mellem kunst, æstetik og politik er sjældent blevet artikuleret så radikalt, som det skete i avantgardebevægelserne, der forsøgte at destruere skellet mellem kunst og liv. Kunsten skulle ud af kunstinstitutionen og ud på gaden, hvor den i samspil med kommunismen skulle revolutionere verden, ophæve kapitalismen og realisere et liv bestående af frihed, leg og fællesskab. Forsøget på at lade kunst og politik smelte sammen kulminerede med avantgardegruppen Situationistisk Internationale, der inspireret af rådskommunisme og surrealisme i årene 1957 til 1972 forsøgte at forene kunstnerisk og politisk avantgarde i revolutionær aktivitet, hvor samfundets repræsentationer blev fordrejet og destrueret. Den følgende fremstilling er en præsentation af situationisternes særlige politisk-kunstneriske praksis og en analyse af deres forsøg på at fordreje samfundets billeder. Udgangspunktet for fremstillingen er aktionen Destruktion af RSG-6, som situationisterne stablede på benene i 1963 på Galleri Exi i Odense. Aktionen i Odense var på én gang en kritik af den samtidige atomoprustning og en kritik af dominerende kunstneriske stile som den abstrakte ekspressionisme. Kun en sådan praksis, som integrerede kritik af både politiske forhold og kunst i samme aktion, kunne ifølge situationisterne undgå at bekræfte den allerede eksisterende kapitalistiske verden. Med omdrejningspunkt i aktionen i Odense præsenteres og diskuteres situationisternes teorier og praksis med særligt henblik på forholdet mellem kunst, æstetik og politik.

\section{Avantgardens projekt og historie}

Et af kunstens mest fascinerende og særprægede fænomener i det 20. århundrede var avantgardebevægelserne, som havde til hensigt at destruere kunsten og skabe et nyt menneske. Fri for den formålsrationalitet og akkumulationstrang, som ifølge avantgarden kendetegnede det borgerlige kapitalistiske samfund, ville de skabe et liv, hvor kunst, politik og hverdag smeltede sammen i en højere enhed. ${ }^{1}$ Futuristerne ville oversvømme kunstmuseerne, dada erstattede det traditionelle auratiske kunstværk med en spøg og surrealisterne bestræbte sig på at frisætte så megen skaberkraft som muligt. Alle var de karakteriseret ved en ubønhørlig antipati mod det samtidige samfund, hvor aristokratiet stadigvæk spillede en central rolle kulturelt og politisk, hvor den teknologiske udvikling var i sin vorden, og hvor den politiske horisont var radikalt åben - kommunismen og nazismen var radikale udfordringer til det daværende ustabile demokratiske system. Disse bevægelser var mindst lige så optaget af at benytte deres visuelle
1 Jf. Peter Bürger: Theorie der Avantgarde (Frankfurt: Suhrkamp, 1974). 
og spatiale praksis i et politisk engagement, som de var optaget af at fortsætte den moderne kunsts eksperimenteringsproces. Det politiske engagement var centralt for avantgarden, som ønskede at destruere skellet mellem kunst og liv for derved at muliggøre en æstetisering af hverdagen. Det æstetiske potentiale, som i stigende grad var blevet indespærret i kunstens sfære, skulle slippes fri i hverdagen.

Avantgardegrupperne ville sprænge kunstinstitutionen og protesterede mod sammenhængen mellem autonomi og konsekvensløshed. De rettede derfor ikke et angreb mod forskellige enkeltværkers indhold - de rettede et angreb mod kunstens funktionsmåde i samfundstotaliteten. De ville føre kunsten tilbage til livet, men ikke livet som det blev defineret af det borgerlige samfunds formålsrationalitet. Derfor allierede de forskellige avantgardegrupper sig med nogle af de politiske bevægelser og partier, som ligesom avantgarden var kritiske overfor det samtidige samfund. Forskellige kommunistiske og venstreorienterede bevægelser var yndede samarbejdspartnere. I Sovjetunionen i den første halvdel af 1920'erne efter revolutionen i 1917 kastede de russiske avantgardekunstnere sig med frådende appetit over projektet at skabe en ny proletarisk kultur: Aleksand Rodchenko indrettet arbejderklubber, Vladimir Tatlin lavede sit monument for den III. Internationale og Vladimir Majakovski propaganderede i tekst og tale for revolutionen. Forfatteren blev med Sergej Tretjakovs ord en revolutionær journalist. Denne socialistiske æstetisering af hverdagslivet blev imidlertid hurtigt standset af stalinismens dogmatiske og skånselsløse partimaskineri, der ikke levnede plads til andre projekter end det stalinistiske gesamtkunstwerk og dens propagandaoffentlighed. Det gik ikke de andre avantgardegrupper meget bedre: Futuristerne oplevede et stort mandefald i 1. verdenskrig, der ellers var blevet lovsunget af futuristerne som en rensende operation, der skulle regenerere den italienske Nation. Efter krigen accentuerede Marinetti futurismens nationalisme og indledte et samarbejde med Mussolinis fascistiske parti og futurismen fandt sin plads i fascismens hegemoniske pluralisme side om side med andre moderne og klassiske kunstneriske stile. Dada sprang i fuld overensstemmelse med gruppens modsætningsfyldte karakter relativt hurtigt i luften, men vedblev bl.a. i Berlin med, indtil 1930'ernes begyndelse, at formulere en radikal kritik af det politiske establishment og kunstscenen, som det kom til udtryk i f.eks. John Heartfields antinazistiske fotomontager. Surrealismens forsøg på at revolutionere eksistensen medførte et kompliceret samarbejde med det franske kommunistparti. Da dette sam- 
arbejde ikke længere gav mening i takt med Sovjetunionens og det franske kommunistpartis rigide historiske materialisme, trak surrealisterne sig gradvist tilbage fra deres tidligere politiske engagement og koncentrerede sig om at udvikle surrealismen som en kunstnerisk stil. Ingen af avantgarderne overlevede 1930'erne. Alle brød de sammen konfronteret med fascisme, stalinisme og verdenskrig. Opkomsten af konsumsamfundet i Vesteuropa konfirmerede blot denne udvikling.

Avantgardens revolutionære projekt overlevedeikke 1930'erne. Det centrale samarbejde mellem den kunstneriske avantgarde og de forskellige kommunistiske bevægelser blev kompliceret op gennem 1920'erne i takt med Sovjetunionens tiltagende 'nationalisme'. Samtidig var det revolutionære afsæt og det antiimperialistiske opgør blevet kanaliseret over i fascisme i 1922 i Italien og senere i Tyskland og Spanien. Derved blev den politiske horisont voldsomt indsnævret, og den revolutionære dynamik trængt i defensiven. Nazismen og stalinismen standsede på denne måde avantgarden. De totalitære løsninger holdt imidlertid kun stand i Sovjetunionen, i resten af Europa og USA blev det borgerlige demokrati en ubestridelig realitet efter den 2. verdenskrig. Universaliseringen af det borgerlige demokrati og oppositionen til den sovjetrussiske kommunisme lukkede effektivt den politiske horisont. Revolutionen var ikke længere i luften, som den havde været i 1910'erne og 1920'erne. Den kolde krig og delingen af Europa gjorde en revolution urealistisk. Der var ikke længere noget alternativ til den bureaukratiserede kapitalismes vareproduktion, hvor forbrug og kultur smeltede sammen. De socio-historiske mulighedsbetingelser, som havde skabt grundlaget for avantgarden, var ved at forvitre. Den sociale utopisme, som drev den historiske avantgarde frem og gjorde det muligt for dens kunstnere at alliere sig med den venstreorienterede politiske kultur, var ved at forsvinde. Enhver utopisk vision blev betragtet med skepsis, og oplysningsprojektets traditionelle kritiske plads blev opgivet, hvorefter der ikke var andet at gøre for kunstnerne end ironisk at tilegne sig sen-kapitalismens logik. Den kritiske distance mellem æstetisk erfaring og instrumentel fornuft blev opløst, og avantgardepositionen forsvandt. Størstedelen af de samtidige europæiske kunstnere oplevede den amerikanske rekonstruktion af Europa som en mulighed og ikke som en begrænsning. Afslutningen på den 2. verdenskrig blev samtidig oplevet som en befrielse, og de frygtelige omkostninger ved den antifascistiske krig blev efter kort tid stødt til hvile i genopbygningen af nationale identiteter. På grund af den historiske erfarings komplicerede status - for- 
trængning af kollaborationspolitikken og undertrykkelse af den antifascistiske kamps antibiopolitiske potentiale samt affirmationen af forbrugssamfundet - mistede efterkrigstidens kunst den direkte forbindelse til den historiske avantgarde. Dennes angreb på kunstinstitutionen og engagement i en revolution af de samfundsmæssige forhold syntes ikke længere mulig. Kunstens produktions- og receptionsbetingelser var under voldsom forvandling og gjorde tilsyneladende avantgardens projekt sværere at gennemføre end før den 2. verdenskrig, hvis ikke de direkte fjernede grundlaget for det. Grundlaget for den politisk engagerede kunst eroderede således gradvist i takt med, at kunstinstitutionen blev mere og mere magtfuld, og at de rekonstruerede samfund benyttede billedet som konsummobilisator.

Der var imidlertid få undtagelser til denne udvikling, hvor det dominerende abstrakte maleri blev synonym med individuel frihed, og hvor forsøget på at sprænge institutionen gik i glemmebogen, en af disse undtagelser var Situationistisk Internationale. Situationisterne konfronterede efterkrigstidens rekonstruerede Europa og dets æstetiserede konsumoffentlighed med en profetisk vision om et fremtidigt samfund uden penge, stat og arbejde. Det kapitalistisk opsplittede samfund, af situationisterne benævnt skuespilsamfundet, blev holdt falsk sammen af billeder, af repræsentationer som journalistikken, reklamen, den politiske propaganda og massemedierne cirkulerede. Disse repræsentationer ville situationisterne fordreje eller smadre. I et samfund domineret af billeder gav det æstetiske ikke længere mening. Kunsten var død, nu måtte den virkelige avantgarde forlade kunsten og realisere den direkte i hverdagslivet, æstetikken skulle vristes løs fra den kapitalistiske valorisering og sættes fri i hverdagen. Fordi skuespilsamfundet blev holdt sammen af billedlige og æstetiske dominansformer, modarbejdede situationisterne konsekvent enhver forestilling om det æstetiske. Det æstetiske gav simpelthen ikke længere mening, da skuespillet havde skabt en overhængende og anæstetiserende pseudoverden. Situationisterne kæmpede indædt mod det æstetiske, i betydningen et anæstetisk skuespil, der tvang folk til passivt at kontemplere deres eget liv, med det håb at befri mennesket fra billedet.

\section{Destruktion af RSG-6}

Den 22. juni 1963 åbnede udstillingen Destruktion af RSG-6 i Galerie Exi i Odense. Udstillingen blev lanceret som en kollektiv manifestation af Situationistisk Internationale' og var en hyldest til de 
anonyme englændere, der samme år i april måned under navnet "Spies for Peace" havde afsløret den engelske regerings hemmelige konstruktion af et atombombesikkert beskyttelsesrum kaldet RSG-6. Udstillingen bestod af tre sektioner - i den første sektion Beskyttelsesrum var et rum indrettet som et beskyttelsesrum med brikse langs væggene, konservesdåser og vandflasker stablet op i et hjørne. På briksene var der placeret mannequindukker i ligposer. Rummet var næsten mørklagt, kun én enkelt elpære blinkede uregelmæssigt. På væggen stod der "RSG-6". En kraftig lugt fyldte rummet og der lød hylende sirener. To assistenter klædt i beskyttelsesdragter gik rundt i rummet og uddelte små piller til de besøgende. I den anden sektion Revolte var der ophængt skydeskiver, hvorpå fotografier af datidens politiske ledere var fastgjort: Den amerikanske præsident Kennedy, den sovjetiske ministerpræsident Nikita Krustjov, den franske præsident Charles de Gaulle, Spaniens Francisco Franco, Vesttysklands forbundskansler Konrad Adenauer og den danske udenrigsminister Per Hækkerup. I sektionen fik publikum udleveret luftgeværer, som de skulle bruge til at skyde på billederne af de forskellige politikere med. På væggene hang desuden en række hvide lærreder, hvorpå situationisten Guy Debord havde skrevet forskellige paroler: Abolition du travail aliéné (Ophævelse af det fremmedgørende arbejde), Dépassement de l'art (Overskridelse af kunsten), Réalisation de la philosophie (Realisering af filosofien), o.a. I tredje sektion Udstilling fik beskuerne en cocktail, de kunne drikke, mens de kiggede på den serie billeder, der hang på væggene, eller mens de kiggede i kataloget, der lå fremme. Den ene af de serier, som hang på væggene, var situationisten J. V. Martins 'Termonukleare kartografier' - en serie malerier, som viste forskellige dele af jorden efter udbruddet af den 3. verdenskrig. Den anden serie var situationisten Michele Bernsteins 'Victoires du prolétariat' (Proletariatets sejre) - en serie relieffer, der afbildede proletariatets historiske nederlag som sejre. [evt. illustration ind her]

Med disse få ingredienser forsøgte Situationistisk Internationale at skandalisere ikke blot kunsten, men hele verden. Situationisterne forsøgte med udstillingen at forholde sig til en højst eksplosiv politisk situation og forsøgte at lægge afstand til både den samtidige kunstproduktion og den samtidige politiske retorik. Udstillingen var intenderet som element i en radikal og altafvisende samfundskritik, der trak veksler på socialismens revolutionære teorier som rådskommunismen og anarkismen. Fra disse teorier og traditioner hentede situationisterne en udfoldet kritik af den etablerede økonomisk-politiske orden i verden med 
2 For introduktioner til Situationistisk Internationales teori, se f.eks. Anselm Jappe: Guy Debord (Pescara: Edizioni Tracce, 1993), Mario Perniola: I Situazionisti. Il movimento che ha profetizzato la 'Società dello spettacolo' (Roma: Castelcecchi, 1998), Peter Wollen: "Bitter Victory: The Art and Politics of the Situationist International", Elisabeth Sussman (ed.): On the Passage of a Few People through a Rather Brief Moment in Time: The Situationist International 1957-1972 (Cambridge, Mass. \& London: MIT Press, 1989), pp. 20-61 og Mikkel Bolt: Den sidste avantgarde. Situationistisk Internationale hinsides kunst og politik (København: Forlaget Politisk Revy, 2004).

3 Guy Debord: "Situationisterne og de nye aktionsformer i politik og kunst", Destruktion af RSG-6 (Odense: Galerie Exi, 1963), p. 3 . dens penge- og statsmagt samt en kritik af de former for kritik, som blot krævede begrænsede omkalfatringer af denne orden og ikke den umiddelbare afskaffelse af staten og lønarbejdet. Denne kætterske socialisme kombinerede situationisterne med den kritik af kunsten, som mellemkrigstidens kunstneriske avantgarde havde formuleret. ${ }^{2}$ Dada og surrealisme havde i perioden fra 1916 til 1930 henholdsvis negeret og realiseret kunsten ifølge situationisterne. Dada havde erstattet det traditionelle auratiske kunstværk med en spøg, mens surrealismen havde brugt kunst som et privilegeret instrument til at frisætte så megen skaberkraft som muligt. Begge grupper havde været skeptiske overfor modernismens autonomi, der tillod kunsten at tematisere sociale og politiske emner, men uden at denne tematisering fik nogen social effekt. Kunstens autonome status fungerede som reservoir for den fantasi, der alle andre steder var blevet udryddet i samfundets moderniseringsproces. Denne fantasi ville mellemkrigstidens avantgarde sætte fri i et samfund, som de mente var karakteriseret af instrumentel fornuft. Situationisterne ønskede at fortsætte dadas og surrealismens projekt, de ønskede at forkaste den daværende verden til fordel for den virkelighed og oprindelighed, som fandt sit udtryk i den radikale subjektivitet, dvs. i oprørene mod denne verdens institutioner og i det revolutionære proletariats selvstændige organisering.

I kataloget til udstillingen Destruktion af RSG-6 skrev lederen af Situationistisk Internationale Guy Debord: "Den situationistiske bevægelse forener sig i tre ting: Den er en kunstnerisk avantgarde, den søger gennem eksperimenter at finde vejen til menneskets frie tilrettelæggelse af sit daglige liv, og endelig medvirker den ved den praktiske og teoretiske opbygning af en ny revolutionær afvigelse. For fremtiden må al grundlæggende kulturel skaben og enhver kvalitativ omdannelse af samfundet udsættes, indtil fremskridtet er i gang på alle disse områder i fællesskab." ${ }^{3}$ Sætningerne fremmaner en tid, hvor det stadigvæk var muligt at forbinde kunst og politik. Den kunstneriske avantgarde skulle være den politiske avantgarde. Den samtidige verden skulle transformeres, og kunstnere havde en central rolle at spille i denne transformation. Samfundet skulle forkastes en bloc. Debord og situationisterne havde en vision om et andet liv, derfor skulle samfundet afvises og forvandles. Situationistisk Internationale stillede sig i revolutionens tjeneste.

Debord formulerede disse sætninger på et tidspunkt, hvor de vesteuropæiske samfund gennemgik voldsomme sociale og historiske transformationer, der også forvandlede kunsten. Sætning- 
erne er et produkt af en tid, hvor kunst var impliceret i fremkomsten af nye økonomiske og symbolske produktionskræfter og produktionsrelationer, som på længere sigt syntes at komplicere, hvis ikke ligefrem at umuliggøre foreningen af kunstnerisk praksis og politisk refleksion i én og samme handling. ${ }^{4}$ Det var ikke desto mindre hvad Debord ønskede. Debord og situationisterne forsøgte derfor febrilsk at komme på højde med disse nye betingelser i håbet om at kunne være med til at formulere en alternativ og 'fremtidig' politisk-kunstnerisk praksis. Selvom vi stadigvæk, måske særligt gennem det sidste årti, har været og er vidner til kunstneriske praksisser, som eksplicit forholder sig til sociale og historiske begivenheder, ${ }^{5}$ så fremstår Debords proklamatoriske fraser underligt fremmede. Hvis kunst og politik kædes sammen nu, sker det så at sige aldrig så ligetil, som det skete i Debords sætninger, der ikke levnede tvivl om hensigten. Situationisterne ønskede at forene politisk engagement med kunstnerisk eksperiment. Det betød, at for Debord og situationisterne var kunst kun af betydning, for så vidt som kunst agerede ikke blot kritisk, men revolutionært i forhold til det omgivende samfund. En sådan fordring til kunsten og tiltro til dens betydning virker om ikke malplaceret, så dog aparte på et tidspunkt, hvor ingen er i tvivl om kunstinstitutionens magt og betydning, og hvor få sætter spørgsmålstegn ved kapitalens evne til selvreform og det gunstige i kombinationen af liberalt demokrati og markedsøkonomi. ${ }^{6}$

Midt i efterkrigstidens omfattende sociale og økonomiske omvæltninger var det ifølge situationisterne ikke muligt at tage et mere 'realistisk' standpunkt som minimalisterne og popkunstnerne indenfor kunsten gjorde det, eller som den etablerede venstrefløj gjorde det indenfor politikken. Som i de tidligere revolutionære øjeblikke, situationisterne var så draget af, var det et spørgsmål om alt eller intet. Situationisterne ville ikke stille sig tilfreds med mindre reformer og de valgte alt, selv om dette forcerede spring ind i fremtiden kunne efterlade dem med intet. Forceret fordi situationisterne oplevede samtiden som et skuespil, hvor falske repræsentationer havde standset historien og annonceret dens afslutning. Situationisterne accepterede ikke denne afslutning på historien og ville ikke stille sig til tåls med pragmatisk at bearbejde denne udvikling formelt og skabe små underlige objekter som minimalisterne eller popkunstnerne, der ironisk omfavnede konsumsamfundets nye varer og objekter og forstyrrede den kulturelle logik bag produktionen og cirkulationen af varen.

Situationistisk Internationale var konciperet som den historiske nødvendigheds fortrop og agerede midt i fjendens territorium,
4 Jf. Perry Anderson: "Modernity and Revolution", A Zone of Engagement (London \& New York: Verso, 1992), pp. 25-55, Peter Bürger: Theorie der Avantgarde (Frankfurt: Suhrkamp, 1974).

5 Jf. Mikkel Bolt: "Brudte løfter. Socialt anfægtet kunst, globalisering og politisk offentlighed", Mutér, nr. 3, 2003, pp. 14-19.

6 Jf. Slavoj Zizek: Did Somebody say Totalitarianism? Five Interventions in the (Mis) use of a Notion (London \& New York: Verso, 2001). 
7 For principielle analyser af forholdet mellem kunst, æstetik og politik, se bl.a. Mikkel Bolt: "Kunst, æstetik og politik - stadigvæk”, Simon Lauman Jørgensen (red.): Fra verden til navlen. Spiller kunsten nogen rolle? (Århus: Forlaget Philosophia, 2003), pp. 29-51, Mikkel Bolt: “Æstetik, anæstetik og æstetisk ideologi”, Nordisk Estetisk Tidskrift 24 (2001), pp. 9-32, Salim Kemal \& Ivan Gaskell (red.): Politics and Aesthetics in the Arts (Cambridge: Cambridge University Press, 2000), Jacques Rancière: Le partage du sensible (Paris: La Fabrique, 2000). Æstetik og politik kan forbindes på flere måder. De tre vigtigste måder, hvorpå æstetikken kan have en politisk funktion, vil jeg mene, er 1) forestillingen om den æstetiske smagsdoms grundlæggelse af et politisk fællesskab, 2) kunstens affirmative karakter (den æstetiske 'misforståelse' af kunstværkets funktion) og 3) æstetiseringen af hverdagen, der findes i to modsatte versioner, dels den 'negative' som f.eks. fascismens æstetisering af politikken, dels den 'positive' som avantgardens sammensmeltning af kunst og liv. Det var særligt den tredje funktion, som situationisterne ofrede opmærksomhed på, når de kritiserede den spektakulære markedskapitalisme for at være et anæstetisk skuespil, der på en perverteret måde havde realiseret avantgardens ønske om at sammensmelte kunst og liv. i hvad de kaldte skuespilsamfundet. Situationisterne benægtede denne verdens virkelighedskarakter og forkastede den til fordel for proletariatets selvstændige organisering. Sigtbarheden var lig nul: den kolde krig havde reduceret det politiske spektrum til et spørgsmål om troskab overfor USA's konsumkapitalisme eller Sovjetunionens statskapitalistiske diktatur, og kunsten havde skippet enhver forbindelse til sit tidligere revolutionære projekt. I den situation forsøgte situationisterne at holde mellemkrigstidens avantgardeprojekt i live samtidig med, at de selvfølgelig gjorde opmærksom på, hvilken kraftanstrengelse en sådan opgave krævede, og hvilke drastiske ændringer avantgardens projekt nødvendigvis skulle udsættes for i den nye historiske situation. Denne var nemlig kendetegnet ved en uhørt kapitalistisk konstruktion af 'subjektet', der nødvendiggjorde, at avantgarden fandt frem til mulige modstandsformer mod denne konstruktion og analyserede implikationerne af invasionen og omorganiseringen af hverdagen, en sfære tidligere udenfor varens dominans. Det var netop denne 'kolonialisering af hverdagen', som gjorde spørgsmålet om kunst og æstetik centralt for formuleringen af enhver alternativ politik ifølge situationisterne. Samfundet brugte billeder til at skabe en repræsentation af sig selv, en æstetisk overflade, hvorved enhver fælles identitet blev erstattet af en generaliseret psykosociologi, der absorberede enhver kritik og alle ironiske eller kritiske præsentationer. Skuespilsamfundet havde æstetiseret hverdagen. De billeder, som holdt samfundet sammen, appellerede til folks sanser, men udraderede dem. Skuespilsamfundet var æstetisk i betydningen anæstetisk, det knægtede kroppens sanser. Overfor disse bedrageriske repræsentationer stillede situationisterne den radikale subjektivitets legende fantasi realiseret i dagligdagen. Dér i hverdagen skulle den kunstneriske avantgarde smelte sammen med den politiske avantgarde: i negationen af kunst og politik som adskilte fænomener og realiseringen af dem som én æstetisk aktivitet drevet af revolutionær bevidsthed. Situationisterne ville vende skuespillets anæstetisering på hovedet og effektuere en positiv æstetisering med udgangspunkt i det begær, som den spektakulære markedskapitalisme undertrykte. ${ }^{7}$

\section{Skuespilsamfund og avantgarde}

Udstillingen i Odense var intenderet som et eksempel på en sådan kritik af kunst og politik. Det var i et højspændt politisk klima med truslen om total udslettelse hængende over hovedet, at situationisterne valgte at 'dedikere' deres eneste udstilling i 
7 år til de engelske aktivister "Spies for Peace" og deres aktion, hvor maskerede aktivister med forbindelse til fredsbevægelsen var brudt ind i et af den engelske regerings beskyttelsesrum. ${ }^{8}$ Denne bunker var én i en lang række af beskyttelsesrum, som den engelske regering i løbet af 1950erne havde opført i al hemmelighed. De såkaldte RSG'ere (Regional Seats of Government) var beskyttelsesrum, der skulle huse de lokale politikere og regeringsmedlemmer i tilfælde af en atomkrig. Som sagt foregik konstruktionen af disse beskyttelsesrum uden at den engelske offentlighed havde kendskab til det, indtil aktivister brød ind i RSG-6 bunkeren i Reading og fotograferede bunkeren, de hemmelige dokumenter, som befandt sig der, og de soldater, som arbejdede der. Fredsaktivisterne duplikerede dokumenterne, de fandt og skrev en lille pamflet med titlen "DANGER! OFFICIAL SECRET RSG-6", hvori de offentliggjorde den engelske regerings detaljerede planer i tilfælde af atomkrig. Pamfletten blev derefter sendt til nyhedsbureauer og aviser, og afsløringerne kom straks på forsiden af aviserne og skabte ballade i regeringen. En af de største demonstrationer mod den engelske regering i nyere tid fandt således sted foran RSG-6 bunkeren tre dage efter, at "Spies for Peace" havde afsløret planerne om at isolere regeringen i hemmelige beskyttelsesrum efter et eventuelt udbrud af atomkrig.

Situationistisk Internationale tog udgangspunkt i denne begivenhed. Selvom kunsthistorien er fyldt med eksempler på kunstnere, der tog politiske begivenheder som materiale, og trods bearbejdning efterlod det politiske synligt i kunstværket, ${ }^{9}$ så var situationisternes bearbejdning anderledes. Hvor Rubens eller Tizian omdannede de politiske begivenheder og rensede dem for kontingens, allegoriserede dem, var situationisterne nødsaget til at fastholde det kontingente og tilfældige ved den politiske dynamik, hvis de skulle undgå at reducere denne til æstetik. De kunne ikke transcendere den politiske situation. De kunne ikke omdanne de daglige og kaotiske politiske begivenheder til kosmologiske mirakler, som Rubens og Velázquez gjorde i deres malerier. Den omkalfatring, hvor Rubens og Velázquez gjorde politikken mirakuløs - overgivelse af Breda er lig med indtog i Jerusalem - var ikke til rådighed for situationisterne, der var nødsaget til at kæmpe om denne verden, transformere skuespilsamfundet. Der var ikke andre verdener til rådighed end den, skuespilsamfundet havde besat og eksproprieret.

Begivenhederne i England var altså afsæt for situationisternes udstilling, som fandt sted blot halvanden måned efter at "Spies for Peace" var brudt ind i den hemmelige bunker og havde gjort
8 Jf. "Spies for Peace and after", The Raven. Anarchist Quaterly, nr 5, 1988, pp. 61-96.

9 Modstillingen mellem tidligere kunstneres 'politiske' kunst og situationisternes intenderet postkunstneriske og politiske aktioner trækker på T. J. Clarks korte diskussion af forskellen mellem modernismen og tidligere 'politisk' kunst. Jf. Farewell to an Idea: Episodes from a History of Modernism (New Haven \& London: Yale University Press, 1999), pp. 21-22. 


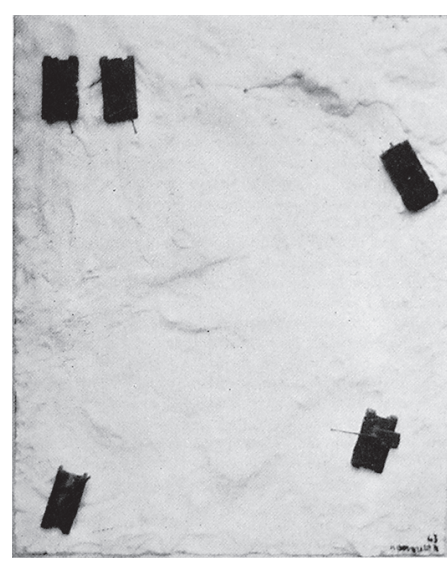

10 Jf. Guy Debords breve til J. V. Martin den 8. maj, til Raoul Vaneigem den 8 juni, til Ivan Chtcheglov den 8 . juni og til Rudi Renson den 21. juni 1963. Brevene er optrykt i Guy Debord: Correspandance. Vol. II: Septembre 1960 - Décembre 1964 (Paris: Fayard, 2001), pp. 222-225, pp. 231-237, pp. 242-244. offentligheden opmærksom på den engelske regerings planer i tilfælde af atomkrig. Det siger sig selv, at udstillingen og dens objekter var skabt i al hast og ikke var resultatet af langsommeligt kunstnerisk arbejde i kunstnerens traditionelle laboratorium, nemlig atelieret. ${ }^{10}$ Der var altså tale om hastigt udførte objekter, som tilsammen ikke blot skulle referere til, men decideret genskrive episoden i England en måneds tid før. Genskrivningen var nødvendig, ifølge situationisterne, idet den aktion, som "Spies for Peace" havde gennemført og rettet mod den engelske stat, skulle sættes ind i den rette sammenhæng. Aktionen var nemlig blot ét eksempel på en begyndende global utilfredshed og protest mod den daværende indretning af samfundet, hvor truslen om atomkrig blev brugt som afpresning af almindelige mennesker, der levede i konstant frygt for udslettelse. Situationisterne ville genskrive afsløringen af de hemmelige beskyttelsesrum ved hjælp af 'kunstneriske' udtryksformer og på et kunstgalleri. Det kunstneriske materiale bestod altså af en social begivenhed. Denne substitution af det traditionelle kunstneriske materiale med et nyt, nemlig sociale og politiske begivenheder, medførte, at den kunstneriske bearbejdning blev tvunget til at accelerere sin produktionsproces og bevæge sig lige så hurtigt som de politiske dynamikker og begivenheder. I modsætning til den traditionelle kunstneriske praksis, som var centreret om evighed og fravær, så var den situationistiske brug af kunst karakteriseret af umiddelbarhed og tilstedeværelse. I situationisternes aktioner blev naturens stofligheder erstattet af et andet stof, nemlig den sociale diskurs, mens plasticitetens formproblemer blev reduceret til spørgsmålet om aktionens synlighed og effektivitet.

Hvis et 'kunstnerisk' udtryk skulle være i stand til at appropriere og fordreje et politisk udsagn, måtte hensyn til den kunstneriske tradition stilles i bero eller direkte afvises. Faktisk var der tale om, at det traditionelle kunstneriske materiale og den klassiske kunstneriske akt ikke blot blev substitueret, men direkte evakueret idet situationisterne approprierede og tilegnede sig de politiske begivenheder. Det kunstneriske materiale og den kunstneriske akt skulle nemlig fremstå som anakronistiske konfronteret med den situationistiske appropriation, som derved synliggjorde kunstværkets fortidighed og forsøgte at effektuere en destruktion af kunsten som adskilt sfære i livet. Det vigtige var at aktionen i Odense formåede at præsentere kritikken af de politiske forhold, i dette tilfælde afsløringen af de hemmelige beskyttelsesrum i England, og kritikken af kunsten som en helhed eller en sammenhængende kritik. Situationisterne forsøgte at 
praktisere, hvad vi kan kalde 'lokal holisme', hvor den enkelte billedlige satsning ikke blot var udtryk for den kunstneriske diskurs, men syntetiserede totaliteten af diskurser i samfundet. Med andre ord, situationisterne efterstræbte at skabe en form for total kontekst-tekst, hvor politisk engagement og kunstnerisk satsning blev forenet i den konkrete og provisoriske placering af et fordrejet udsagn. Som Debord skrev i kataloget til udstillingen, så var manifestationen i Odense en hyldest og et bidrag til kampen mod den dominerende organisering af det sociale rum, men den var også "dens udbredelse til en anden front, til den kunstneriske side af samme globale kamp. Den kulturelle skaben, som man kan kalde situationistisk, begynder med planerne for [...] skabelsen af livssituationer, og virkeliggørelsen heraf kan altså ikke deri adskilles fra historien om bevægelsen for virkeliggørelsen af alle de revolutionære muligheder, som det nuværende samfund indeholder."11 Datidens revolutionære muligheder blev imidlertid ifølge situationisterne brugt kontrarevolutionært til at styrke den kapitalistisk-borgerlige verden.

Kontrarevolutionen var for situationisterne ikke blot en voldelig undertrykkelse eller en reetablering af den sociale orden, som havde været revet fra hinanden som følge af konflikter og revolter. Med reference til den marxistiske tradition, som situationisterne allerede på dette tidspunkt så sig som en forlængelse af, opfattedes kontrarevolutionen som revolutionen vendt på hovedet. ${ }^{12}$ Den indebar en voldsom udvikling af produktionsmåder, livsformer og sociale relationer, som konsoliderede og ikke afskaffede den kapitalistiske orden. Situationisterne så kontrarevolutionen som den bevægelse, der havde overtaget dynamikken i det politisk-økonomiske opbrud, som den vestlige verden havde oplevet i begyndelsen af det 20. århundrede. Dette opbrud eller revolutionære sagsforhold var blevet kanaliseret over i en kontrarevolutionær erstatning, som ikke stillede spørgsmålstegn ved den kapitalistiske indretning af samfundet. Derved var revolutionen blevet afsporet, og de historiske betingelser, der havde nødvendiggjort revolutionen, indgik nu bekræftende i kapitalens organisering. Massernes egalitaristiske forhåbninger var ikke blevet indfriet.

Således så situationisterne sig selv som konfronteret med en udvikling, hvor de selv samme økonomiske, sociale og kulturelle potentialer, som revolutionen skulle have taget afsæt i, blev benyttet til at stadfæste kapitalismen og dens fremmedgørende mekanismer. Kløften mellem en kapitalistisk og en rationel brug af de nye produktivkræfter voksede imidlertid konstant ifølge

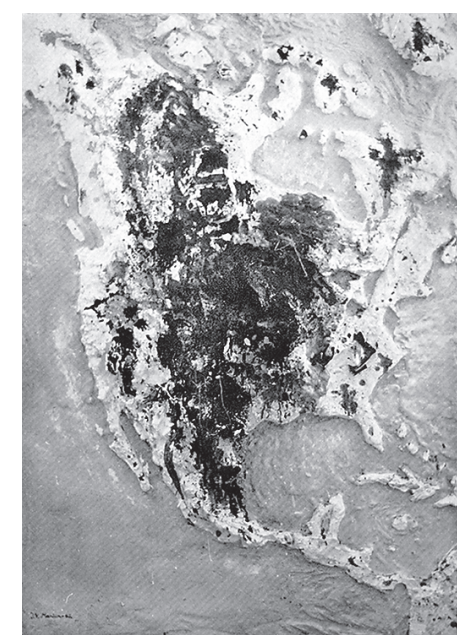

11 Debord: "Situationisterne og de nye aktionsformer i politik og kunst”, p. 5 .

12 Som allerede skrevet trak Situationistisk Internationale veksler på rådskommunismen og på filosoffer som Georg Lukács og Karl Korsch. Det var i denne tradition, særligt hos Korsch, at situationisterne fandt en udfoldet teori om kontrarevolutionen. For præsentationer af situationisternes politiske teorier i forhold til surrealismen, det franske Parti Communiste, trotskismen og rådskommunismen, se Mikkel Bolt: "The Situationist International, Surrealism, and the Difficult Fusion of Art and Politics", Oxford Art Journal, nr. 3, 2004, pp. 356-387. For en redegørelse for Debords brug af Lukács, se Jappe: Guy Debord. 
13 Guy Debord: "Rapport sur la construction des situations et sur les condi tions de l'organisation et de l'action de la tendance situationniste internationale", Gérard Berreby (red.): Documents relatif à la fondation de l'internationale situationniste (Paris: Éditions Allia, 1985), p. 609. situationisterne, og genkomsten af en kraftfuld revolutionær bevægelse var umiddelbart forestående. Situationisterne skulle i den situation sørge for, at den revolutionære bevægelse ikke stillede sig tilfreds med reformer. Kun den absolutte revolution var i situationisternes øjne relevant. Dette alene kunne muliggøre realiseringen af de nye behov og begær, der var opstået i takt med den historiske udvikling.

Kun en total og altafvisende samfundskritik havde betydning for situationisterne, idet de var af den overbevisning, at gradvise og partielle imødekommelser af radikale krav blot forstærkede den kontrarevolutionære dynamik. I et forsøg på at skjule modsætningen mellem de nye muligheder og den kapitalistiske indretning af samfundet forsøgte kontrarevolutionen således ifølge situationisterne at videreføre det revolutionære afsæts kulturelle og ideologiske former, for derved at undgå den radikale opposition til fordel for en 'blødere' og gradvis udjævning. Samtidig håbede den således på at forvirre de potentielt revolutionære subjekter. "Det primære mål for den dominerende klasses ideologi er forvirring", ${ }^{13}$ skrev situationisterne i deres karakteristiske konfrontatoriske stil, der ikke levnede plads til tvetydighed eller kompromis. Hvis situationisterne skulle gøre sig håb om at undgå at støtte den dominerende orden, måtte de gå frontalt til angreb på denne. Den falske videreførelse eller kontrarevolutionære erstatning tog nemlig form af delvise anneksioner af de nye værdier.

I modsætning til tidligere samfund, som blot havde forbudt eller censureret den eksperimenterende kunst og den kritiske intelligentsias aktivitet, så situationisterne og den revolutionære bevægelse sig som konfronteret med et samfund, der gav sine kritikere en plads i rampelyset, for derved at uskadeliggøre dem og reducere dem til intern skepsis og præmis for mindre reformer, der ikke rokkede ved samfundets struktur. På denne måde integrerede og afsporede den borgerlige klasse ifølge situationisterne avantgardekulturen. De fordrejede simpelthen den revolutionære bevægelses kulturelle produktioner, banaliserede dem og cirkulerede dem derefter som sterile fragmenter uden forbindelse til deres oprindelige kritiske afsæt og intention. Denne operation, af situationisterne benævnt 'rekuperation', gjorde enhver kritik diffus og adskilte ethvert potentielt revolutionært udsagn fra sin sociale sammenhæng. Det kapitalistiske samfund forsøgte ifølge situationisterne at integrere enhver kritik ved at individualisere den, ved at isolere få, synlige 'kritikere' og lade disse repræsentere og eksemplificere samfundets tolerance og selvkritik. Samfundet 
var kendetegnet ved, hvad vi hinsides situationisterne kan kalde, en hegemonisk pluralisme, hvor kritik ikke var forbudt eller blev synligt censureret, og hvor eksperimenterende kunst ikke blev direkte indrulleret i statens mekanismer. I stedet blev der ifølge situationisterne gjort alt for, at en overflod af forskellige stile og udtryksformer var til rådighed. Derved blev der skabt en smagsfragmentering, der gjorde det umuligt at knytte de forskellige udtryk sammen og forbinde dem med samfundet på en mere grundlæggende måde. I en sådan situation var forestillingen om avantgarde ifølge situationisterne på en og samme tid suspekt og uundværlig. Suspekt fordi samfundet klistrede avantgardeetiketten på snart sagt alle produktioner, der blot repeterede tidligere udførte formelle eksperimenter. Uundværlig fordi kun takket være bevidsthed om den historiske situation kunne en subversiv indsigt tilvejebringes og samfundet kritiseres. Uden en forudgående samfundsanalyse var enhver gestus i den kulturelle sfære konformitetsopbyggende. Med udgangspunk i situationisternes historiefilosofiske forestillinger - det primitive liv var kendetegnet ved et fællesskab, som blev destrueret af kapitalismen, der nu falsk holdt verden sammen - præsenterede avantgarden sig som et produkt af den historiske udvikling, der havde skabt nye muligheder, som imidlertid blev holdt indespærret i forældede kapitalistiske strukturer. I denne situation var det avantgarden, som på trods af sig selv skulle åbenbare og overvinde denne historiske blokering.

\section{Manifestationen}

Ifølge Situationistisk Internationale var den moderne kunst død - det var ikke længere muligt at skabe isolerede kunstværker uden en forudgående teori om og analyse af den historiske udvikling og samfundets indretning. Derfor skulle kunst og politik som to adskilte og autonome diskurser på én og samme tid destrueres og realiseres. De skulle smelte sammen i den revolutionære kritik af det skuespilsamfund, hvis virkelighedskarakter situationisternes så hårdnakket benægtede. Samfundet havde ifølge situationisterne ved hjælp af kulturen, reklamen, massemedierne og journalistikken udviklet sig til et skuespilsamfund kendetegnet ved fremmedgørelse og iscenesættelse. Mennesket levede ikke i dette samfund, det 'overlevede' blot og kontemplerede passivt de billeder af samfundet, som samfundet producerede og cirkulerede for at skjule en forarmet eksistens. Kultur og kapital var smeltet sammen i en spektakulær vare, med hvilken samfundet 
14 Truslen om atomkrig var et gennemgående tema hos situationisterne i begyndelsen af 1960'erne. I 1962 planlagde Asger Jorn (som på det tidspunkt ellers havde forladt Situationistisk Internationale) og Guy Debord at etablere et nyt tidsskrift med navnet Mutant, der skulle kritisere både Vestblokkens og Østblokkens atomforsvar og den civilisation, de skulle beskytte. I teksten "Geopolitique de l'hibernation" (Internationale situationniste, nr 7, 1962, pp. $3^{-10)}$ analyserede situationisterne terrorbalancen og beskyttelsesrummets ideologi. solgte billeder og forestillinger om 'frihed' og 'demokrati' som erstatning for en autentisk fantasi, som erstatning for sande billeder. I denne situation så situationisterne det som deres opgave, avantgardens opgave, at udvikle og realisere en teori, som knyttede den overordnede kritik af den politiske økonomi sammen med kritikken af dagligdagen med henblik på at lokalisere en virkelighed eller oprindelighed, der ikke var spoleret af skuespilsamfundets billeder. I det følgende ser vi nærmere på, hvorledes situationisterne i Odense-aktionen konkret forsøgte at syntetisere en kritik af politiske forhold med en kritik af kunsten.

Som allerede skrevet var udstillingen Destruktion af RSG-6 delt op i tre sektioner. Det første rum, de besøgende kom ind i var 'Beskyttelsesrum', der var udstyret så det lignede et sådant. Situationisternes forvandling af gallerirummet til et dystert beskyttelsesrum, må forstås i umiddelbar forlængelse af Cubakrisen, hvor hele verden øjensynligt med nød og næppe lige havde undgået en altudslettende atomkrig. Installationen var ifølge situationisterne et billede på det daværende samfund, som i frygt for atomkrig havde forvandlet eksistensen til en trøstesløs og minimal opretholdelse af livet. ${ }^{14}$ Mere grelt kunne situationisterne næsten ikke afbilde det omgivende samfunds aktuelle atomfrygt. En frygt som ifølge situationisterne skjulte stormagternes fælles projekt: Nemlig reduktionen af det menneskelige liv til ren overlevelse. Den kolde krigs to kombattanter udsatte ifølge situationisterne verdensbefolkningen for dobbelt afpresning: Hvis man afviste at tage stilling, var man sikkert placeret i den vestlige verden, hvor man frit valgte; hvis man gjorde opmærksom på kapitalismens suspekte følger, kunne man ikke undgå at fremstå som tilhænger af den sovjetiske kommunisme. Situationisternes konsekvente løsning var at afvise selve modstillingen. Situationisternes hegeliansk-marxistiske historieforståelse gjorde dem i stand til at læse den komplicerede og uoverskuelige situation som en totalitet: Der var intet valg mellem disse to positioner, de var begge ensidige og falske. At indtage et sådan standpunkt i den kolde krig var en falsk abstraktion. Pointen var, at de to sider ikke i virkeligheden var modstillede, men at de var en del af samme falske virkelighed, der skulle udfordres gennem den bevidste revolutionære handling.

I den anden sektion skulle publikum skyde på skydeskiverne med billeder af de politiske ledere. Den traditionelt passive kunstbeskuer, der kontemplerer malerier, skulle aktiveres og angribe repræsentationer af de forskellige politiske ledere, der alle ifølge situationisterne var medansvarlige for verdens tilstand og for 
at havde reduceret den menneskelige tilværelse til en trist eksistens i et beskyttelsesrum. Den blotte overlevelse, som frygten indskrænkede livet til, skulle udfordres gennem den hyper-ikonoklastiske handling at skyde på billeder. Det ophøjede galleri til beskuelse af kunstværker blev forvandlet til en slagmark, hvor de cirkulerende og dominerende billeder blev beskudt og destrueret. Ved at hænge de politiske ledere op på væggen som skydeskiver eksponerede situationisterne det politiske establishments synlighedsdyrkelse, det fænomen at politik handlede mere om en politikers fremtoning på skærmen end om vedkommendes politiske holdninger. Ved samtidig at hænge Kennedy og Krustjov skulder ved skulder forkastede situationisterne kold-krigsdiskursen, der præsenterede de to som inkarnerede fjender, man enten var med eller mod. I stedet understregede situationisterne stormagternes fælles dagsorden: Reduktion af livet til ren overlevelse. Skuespilsamfundets repræsentationer, der forvandlede mennesket til en passiv betragter af egen eksistens, blev ved en enkel fordrejning - placeringen på skydeskiverne - forvandlet til afsæt for en aktivering af mennesket. Beskuerne blev aktive deltagere i en kritik af samfundets indretning. Ophængningen af de politiske skydeskiver rummede utvivlsomt en henvisning til surrealismen og til André Bretons dictum om, at den surrealistiske handling par excellence var at gå ned på gaden og skyde ind i menneskemængden. ${ }^{15}$ Hos situationisterne var den radikale handling imidlertid ikke længere blot en metafor, den var blevet reel, situationisterne havde forladt fantasiens verden og fået et klart sigte: Kontrarevolutionens hoveder, skuespilsamfundets politiske repræsentanter, skal beskydes. Der skulle ikke længere skydes på må og få ind i menneskemængden: Nu skulle skytset rettes mod skuespilsamfundets ledere og mod skuespilsamfundets repræsentanter. Når disse repræsentanter blev beskudt, gennemhullede og faldt til jorden, ville skuespilsamfundet ligeledes falde.

I samme sektion hang Debords direktiver. Fire af direktiverne var aflange tomme lærreder, hvorpå der var skrevet med sort maling. Teksterne var tilsyneladende skrevet hurtigt og direkte på lærrederne. Bogstaverne var ikke alle lige store, og ordene stod ikke særligt harmonisk på fladen, men 'tiltede' og vippede. Direktiverne hang i forskellig højde ved siden af hinanden og skulle ifølge Debords katalogtekst minde beskueren om de slogans eller den graffiti, der prægede murene i byerne. Med direktiverne forsøgte Debord at underminere det maleriske medium og forsøgte at $ø$ mme det for mening. Han reducerede maleriet til en tavle eller mur og negerede derved maleriet som billede og destruerede
15 Jf. André Breton: Second manifeste du surréalisme, Manifestes du surréalisme (Paris: Gallimard, 1992), p. 74. 
dets privilegerede status. Direktiverne pegede ud af kunsten og ud i verden. De hvide lærreder med lidt gnidrede bogstaver afviste ethvert ønske, beskueren måtte have om kontemplation. Der var ingen visuel nydelse i direktivernes kontante sætninger. Det moderne maleris eksperimenterende anstrengelser med farver, former og figurer var afløst af agitation. Kommunikation af teori havde afløst visuel konsumption. Hverken vindue eller flade, men forstørret plakatsøjle eller mur. 'Videre, der er ikke noget at se, videre', syntes Debord at sige. Der var intet kunstnerisk interiør at forvilde sig rundt i, der var ingen subjektiv repræsentation, der var ingen kunstnerisk tilstedeværelse i direktiverne. Der blev blot eksponeret en upersonlig objektivitet. Den moderne kunst skjulte verden og dens muligheder under et tykt lag maling, der nu skulle opløses som i et syrebad for at lade en revolutionær bevidsthed komme til syne.

Det femte direktiv var et maleri af den italienske kunstner Pinot Gallizio, hvorpå Debord havde skrevet: Abolition du travail aliéné (Ophævelse af det fremmedgørende arbejde). Den kreativitet, som var spærret inde i den kunstneriske praksis, skulle generaliseres. Kunst som repræsentation af et liv i leg og passion skulle transcenderes. Som alt andet arbejde var kunst en fremmedgørende aktivitet, idet det var adskilt fra dagligdagen. At være kunstner var at stå i vejen for den kreativitet, som 'kunst' tidligere betegnede. Gallizios maleri var et stykke pittura industriale (industrielt maleri), maleri fremstillet på samlebånd i lange baner på op til 70 eller 90 meter. Dette stykke var et 73 gange 105 cm stort stykke, som var oversprøjtet med mørk maling, der fortættedes rundt om på lærredet. Malingen var blevet sprøjtet ud på et langt lærred, som siden var blevet klippet i stykker. Farverne havde fået lov til at flyde ud i materiel råform, uden at de blev moduleret til genstandsformer. Maleriet fremstod som efterladenskab fra en paradoksal kunstnerisk proces, hvor teknik og spontanitet gik op i en højere enhed af tilblivelse og automatik. Gallizios maleri dannede baggrund for Debords direktiv, der nu spærrede for beskuelse af maleriet. Det retningsløse ved Gallizions maleri var blevet afløst af et stærkt politisk udsagn. Det grænseløse og det sprogløse, som Gallizio flirtede med i maleriet, blev brat afbrudt af Debords ord, der brutalt nægtede beskueren at lade sig opsluge i billedet. Helt i overensstemmelse med situationisternes antipati for kunst som vare var direktivet til salg for $300 \mathrm{kr}$. , mens maleriet uden tekst tidligere havde kostet $6000 \mathrm{kr}$.

I den tredje sektion fik beskuerne en cocktail og så Martins malerier af verden efter den 3. verdenskrig og Bernsteins relieffer 
med proletariatets sejre. J. V. Martins 'termonukleare kartografier' var 100 gange $135 \mathrm{~cm}$. masonit plader, der var blevet beklædt med modellervoks, maling, hår, jernstumper, mug og andet på en sådan måde, at jordens forskellige verdensdele var genkendelige på pladerne. Billederne lignede forstørrede landkort, der var modelleret og derefter malet, så de fremstod tredimensionelle. I stil med traditionelle landkort var områderne, der repræsenterede have, søer og floder, malet blå, mens områder, der gjorde det ud for land, var malet grønne. Ovenpå de grønne områder havde Martin derefter dryppet og klasket sort maling, hår, forskellige jern- og træstykker, så verdensdelene så brændte eller bombede ud. Som titlerne indikerede, var billedserien jo også en gengivelse af verden efter udbruddet af den 3. verdenskrig: To timer efter 3. verdenskrigs udbrud, To timer og et kvarter efter 3. verdenskrigs udbrud, På andendagen siger de, der vil vare 82 megalig, To og en halv time efter 3. verdenskrigs udbrud, RSG 6's krematorium: England, To timer og fyrre minutter efter 3. verdenskrigs udbrud, Hvem der end vandt krigen - vi tabte den. Med kulsort humor havde Martin taget alle samtidens skræmmebilleder på ordet og sat hele verden i brand. Tydeligere kunne det ikke gøres: USA, England, Europa og Sovjetunionen var blevet sprængt i luften med brintbomber - det fremgik af det 'blodige' røde spor af maling og de 'brændte' sorte huller i modellervoksens landkort.

Den 'termonukleare' bearbejdning af landkortene var udført som en form for action-painting, hvor malingen var blevet kastet, smidt eller dryppet direkte på lærrederne uden distancerende mellemled i form af traditionel penselteknik. På grund af landkortene i baggrunden og titlerne havde landkortenes 'ubevidste' og 'kropslige' aftryk en anden karakter end i den abstrakte ekspressionismes action-painting. Den rene og 'gældfri' maleriske gestus blev nemlig instrumentaliseret af Martin, der herved gjorde grin med action-painting'ens naive forestillinger om en ubevidst, eksistentiel dimension i sammensmeltningen mellem maler og billede. Den Innerlichkeit der er forbundet med Action-painting blev afsløret som en kodet struktur, der ikke var transparent. Martin løsnede action-painting'ens 'teknik' fra dens originale symbolske funktion og tingsliggjorde den som stil, afmystificerede den og reducerede den til en æstetisk vare, idet han lod den repræsentere brintbombens ødelæggelse. For Martin var den ekspressive teknik netop en teknik, en stil, som han kunne kopiere, ændre og fordreje. Maleriet var ikke et ubevidst spor af en passioneret væren. Den umedierede 'ekspression' viste sig at være perfekt egnet til at gengive død og ødelæggelse. Det, der i action-paintingen var 
spor efter kunstnerens improviserede forsvinding ind i maleriet, blev hos Martin til kalkuleret repræsentation af brintbombers eksplosioner. I modsætning til de abstrakte ekspressionister, som troede, de forsvandt i maleriet og at de var kreative sjæle opløst i processen, var Martin strateg. Hvor de abstrakte ekspressionister tumlede 'hovedløst' ind i fremtiden, da forudsagde Martin den kynisk og bevidst og planlagde i samme nu en alternativ fremtid. Martins billeder skulle på en gang at kritisere både stormagternes aktuelle politiske adfærd og en af de dominerende kunstneriske praksisser, nemlig action-painting'en.

I samme rum som Martins termonukleare kartografier var en serie relieffer udført af Michéle Bernstein. Reliefferne var lavet af gips, hvorpå Bernstein havde fastgjort forskellige former for legetøj. Victoire des Républicains Espagnols (De spanske republikaneres sejr) var en stor hvid gipsplade med fem plastictanks på. Billedet var ubearbejdet som en helt hvid høj rektangulær flade med få 'standsninger', hvor gipsen havde fået lov til at klumpe eller vokse. Dette relief mindede med sin helt hvide flade om de monokromer, kunstnere som Yves Klein og Pierro Manzoni havde skabt få år forinden. Den store forskel var selvfølgelig, at Bernstein havde klistret de fem sorte plastiktanks på relieffet og derved forvandlet den tørre og støvede overflade til en slagmark. Kleins og Manzonis monokromer var ifølge deres ophavsmænd eksempler på en 'immateriel' kunst, der ikke handlede om det 'synlige' i billedet. Denne forestilling om en immateriel kunst, der eksponerede et særligt affektivt nærvær hinsides det repræsenterende maleris rækkevidde, fordrejede Bernstein med de fem plastiktanks. Det monokrome maleris mytiske og kosmogoniske univers, hvor den affektive påvirkning af beskueren tilbød perception af en 'absolut virkelighed', var ifølge Bernstein og situationisterne en rekurs til en form for kvasi-religiøs kunst. Der kunne ikke være tale om at opgive denne virkelighed, den konkrete hverdag, til fordel for forestillingen om en anden virkelighed. Dette ville blot være at bekræfte skuespilsamfundets løfter om evig lykke ved købet af den nyeste vare. Udfordringen og kritikken af skuespilsamfundet skulle finde sted $i$ skuespilsamfundet. Der var ikke plads til utopier kun konkrete alternativer i skuespilsamfundets rum. Derfor var det vigtigt at udfordre skuespilsamfundets historie og skrive denne om med udgangspunkt i den revolutionære bevidsthed. Det var, hvad Bernstein forsøgte med sine relieffer, som alle tre vendte historien på hovedet og forvandlede revolutionære opstandes nederlag til sejre.

De to andre relieffer Victoire de la Commune de Paris (Pariser- 
kommunene sejr) og Victoire de la Grande Jacquerie en 1358 (Den store bondeopstands sejr i 1358) var ikke som Victoire des Républicains Espagnols (De spanske republikaneres sejr) skrabede og enkle. På dem havde Bernstein dryppet både lys og mørk maling og havde ladet gipsen hobe sig op i mange, små forhøjninger på tværs af reliefferne. Plastiksoldater stod opmarcheret overfor hinanden tværs ned gennem relieffet med Pariserkommunens sejr. Maling var dryppet på gipsen og på soldaterne i små linier og i større klumper, så to fronter tydeligt aftegnede sig. Relieffet med bondeopstandens sejr var også beklædt med maling og plastiksoldater, derudover var en række plastiklastbiler blevet fastgjort rundt omkring i gipsen. Brugen af legetøjssoldaterne og plastiklastbilerne var intenderet som en kritik af den brug af dagligdagsobjekter Nouveau Réalisme-kunstnere, som Arman praktiserede i deres kunst. Disse kunstneres brug af hverdagens objekter var ifølge situationisterne karakteriseret af ligegyldighed eller ligefrem af glæde over konsumsamfundets nye varer og objekter. I stedet for den nye realistiske sensibilitets fejring af den moderne hverdag stillede situationisterne den bevidste fordrejning af dagligdagens objekter. Skuespilsamfundets alt andet end uskyldige legetøj blev således brugt i en legende, men bevidst revision af historien. Leg og bevidsthed gik op i en højere syntese af revolutionær aktivitet, der ikke var kunst. Situationisterne betegnede selv denne ikke-kunst som 'en ny irrealisme'. Det var i denne forståelse ikke muligt at lave en realistisk kunst i et samfund præget af fremmedgørelse og et sådant forsøg ville blot bestyrke de falske repræsentationer. I en verden, der blev holdt sammen af falske repræsentationer, skabte situationisterne fragmenterede og ikke-realistiske billeder, der virtuelt muliggjorde andre repræsentationer.

\section{Fordrejning og indlemning}

Forløbet gennem de tre sektioner var nøje planlagt, og situationisterne præsenterede manifestationen som et fælles projekt, hvor alt fra temaerne og titlerne på de ophængte malerier og relieffer var blevet diskuteret i fællesskab før de blev udført. På kataloget stod der da også 'En kollektiv manifestation af Situationistisk Internationale'. Manifestationens objekter var således ikke resultatet af én kunstners individualitet og kreativitet, men var rekvisitter i et gennemorkestreret og intelligibelt udtryk, hvor de enkelte objekter fungerede som en helhed. Det geniale kunstnerindivid var blevet overskredet af den kollektive destruktion, som 
beskuerne tog del i ved at skyde på Kennedy, Krustjov og paven. Beskuerne blev således ikke blot revet ud af rollen som modtager af æstetiske oplevelser, men blev tvunget til at tage stilling til aktuelle politiske spørgsmål. Den isolerede kreative gestus forsvandt til fordel for objektivitet og upersonlighed. I kataloget var den sidste sektions objekter ganske vist opført, men som 'udstillede arbejder' og ikke som kunstværker. Karakteristisk for denne afsværgelse af værkkategorien var da også, at den pamflet, som "Spies for Peace" havde skrevet, ligeledes var opført på listen mellem J. V. Martins 'termonukleare kartografier' og Debords direktiver. Derved forsøgte situationisterne at afvise forskellen mellem den politiske pamflet og gruppens egne visuelle produkter: De gik alle op i en højere helhed af revolutionær kommunikation.

Det vigtige ved de forskellige udtryk - det være sig den politiske pamflet eller reliefferne - var ifølge situationisterne den effekt, de havde; den kritik de fremsatte af skuespilsamfundet. En kritik som måtte være total og radikal i betydningen at gå til rødderne af det daværende samfunds problemer. Intet var forskånet for denne radikale kritik, og derfor måtte kritikken selvfølgeligt også rettes mod de medier, der så at sige bar eller fremførte kritikken. Disse medier, som f.eks. kunsten eller det politiske manifest, skulle selv negeres. Intet skulle helligholdes i kritikken af skuespilsamfundets generaliserede fremmedgørelse. Der var derfor, ifølge situationisterne, ikke tale om en kunstudstilling i almindelig forstand, men om en manifestation, hvor negationen af politikken blev forenet med negationen af kunsten. Manifestationens ærinde var at sætte affæren fra England ind i et bredere socialt og historisk perspektiv af revolutionære oprør, og udvide antiatomprotesten til kunstens område, hvor der skulle ske en omfattende destruktion af kunsten og dens forældede former. Protesten mod de hemmelige beskyttelsesrum og negationen af kunsten var ifølge situationisterne nemlig to sider af samme sag. Kunstens former og praksisser havde mistet deres troværdighed ikke som følge af individuelle og etiske begivenheder, men som følge af skuespilsamfundets økonomiske og politiske omstændigheder. Totaliteten af det daværende samfund skulle kritiseres. En kritik som resulterede i en destruktion af den kunstneriske praksis, der nu blot blev rekupereret som tekniske specialiteter og kunstneriske varer. Kunstens obsolete, afsluttede eller fragmenterede former skulle overskrides til fordel for den revolutionære aktion, hvori såkaldte 'kunstneriske' medier som maleri og arkitektur i fordrejet form kunne benyttes. Kunstens virtuelle revolution skulle finde sted her og nu i dette liv. Det var ikke 
længere nok at kunst var revolution in absentia - at kunsten kompenserede for revolutionens fravær ved at gestalte dens løfter. $\mathrm{Nu}$ skulle revolutionen realiseres gennem den samtidige destruktion af politikken og kunsten.

Martins termonukleare kartografier, Debords direktiver og Bernsteins relieffer var altså ikke kunst ifølge situationisterne. De var en form for politiske 'anti-tableauer', der var hinsides enhver plastisk skønhed. Kun gennem negation af samtidens billedlige former kunne en samtidig kunst skabes. Som remedier, hvormed situationisterne kunne kritisere andre kunstnere, latterliggøre deres kunstværker og skandalisere verden, havde de kunstneriske midler relevans. Den velrettede hån mod udøvende kunstnere og den totale kritik af samfundet havde afløst skabelsen af kunstværker. De revolutionære studenter fra Venezuela, der den 16. januar 1963 havde smidt bomber mod en kunsttransport med Gauguin og van Gogh malerier, blev derfor også rost af Debord i kataloget til manifestationen i Odense: "Bomberne er en manifestation af den eneste rigtige måde at behandle billeder fra fortiden på: at genindsætte dem i livets spil på en plads, hvor de virkeligt kan få betydning." ${ }^{\prime 16}$ Situationisternes opgave lød rigorøst og effektivt at analysere kunstens virkelige modsigelser, ikke at skabe situationistisk kunst. Kritikken af kunsten kunne ikke tage form af skabelsen af flere kunstværker, hvor eksperimenterende og fragmenterede de end var. Den virkelige kritik af kunsten måtte være den billedløse revolution. Problemet for Situationistisk Internationale var imidlertid blot, at hver gang det kommunistiske fremtidsbillede nærmede sig, mistede det sin karakter af alternativ virkelighed og blev i stedet skuespillets nyeste billede. Appropriation viste sig at være rekuperation. Des mere ihærdigt situationisterne bekæmpede skuespilsamfundets falske virkelighed, des mere iøjnefaldende og synlig blev deres profetiske vision.
16 Debord: "Situationisterne og de nye aktionsformer i politik og kunst”, p. 4 . 